\title{
Relief as a neutral form of aid or a political-communal mobilization? Doing politics in emergencies and war and the politics of aid in Lebanon
}

Lamia Moghnieh

\section{Abstract}

Drawing on the experiences of several activists, experts, and individuals involved in the provision of aid and relief during and after the 2006 July war on Lebanon, this case study explores the issues of neutrality and local commitment in providing assistance during war and conflict. It aims at placing the humanitarian principle of neutrality, a global principle of humanitarian assistance that posits a specific form and stance in providing aid, in conversation with local forms of political and communal mobilization of relief. The purpose of this paper is to unveil the assumptions embedded in the concept of "neutral aid", and the type of politics that apolitical humanitarian action and intervention posit and produce, addressing questions relevant to providing or imposing a neutral form of aid in a politically-charged environment, and the way international professionalized NGOs collaborate and interact with local actors. The paper then proposes a set of recommendations for humanitarian action and practice in Lebanon.

Keywords: July 2006 War, Humanitarian \& Emergency Operations, International humanitarian community

To cite this paper: Lamia Moghnieh, " Relief as a neutral form of aid or a political-communal mobilization? Doing politics in emergencies and war and the politics of aid in Lebanon ", Civil Society Knowledge Center, Lebanon Support, August, 2015 . DOI: 10.28943/CSKC.001.30008.

[ONLINE]:

https://civilsociety-centre.org/paper/relief-neutral-form-aid-or-political-communal-mobilization-doingpolitics-emergencies-and-war

This case study explores the issues of neutrality and local commitment in providing assistance during war and conflict. It aims at placing the humanitarian principle of neutrality, a global principle of humanitarian assistance that posits a specific form and stance in providing aid, in conversation with local forms of political and communal mobilization of relief, by taking as an example the July war in 2006, and its aftermath. The purpose of this case study is to unveil the assumptions embedded in the concept of "neutral aid", and the type of politics that apolitical humanitarian action and intervention posit and produce. What does it mean to provide or impose a neutral form of aid in a politically charged environment during war? What does it mean to ask local actors and collectives to be neutral and act like professionalized NGO workers? This case study draws on the narratives and experiences of several activists $\underline{1}$, experts and individuals who were involved in providing different kinds of aid and relief during the July war and its aftermath, to describe the type of aid and relief provided by them outside of a state and non-state structure, in a volunteered and politically committed way. This study then moves to provide a review of the current anthropological and humanitarian debates and critiques of the neutrality of global aid. A synthesis of activists' experiences and critical literature is then provided 
in order to formulate a set of recommendations for current humanitarian practice and action in Lebanon.

\section{Methodology}

Drawing from in-depth interviews conducted with several individuals about their experiences in providing relief during the war and its aftermath, this case study seeks to highlight the difference between volunteering and engaged forms of local relief that emerge to resist and mobilize against wars, and the humanitarian expectation and framings of "relief" as neutral. The case study is also based on a general review of the literature on the critiques of humanitarian neutrality in war and conflict. By bridging both experiential fieldwork with critical literature on the politics of neutrality in humanitarian action, this study will provide an overview of this discussion in both theory and practice, while drawing recommendations for current humanitarian work in Lebanon. Relying on the previous two case studies published on the experience of several activists, experts and volunteers during the July War in 2006, the study will focus on the politics of communal and committed aid and support during war and its confrontation with a global humanitarian politics that adopts neutrality, in the form of standardized professionalism, as a way to provide aid and support. The first section describes the type of aid and local support that emerged outside state and non-state structures and took on a volunteered and politically committed form in the July War. The second section reviews academic and humanitarian research and debates that critiques and analyzes the principle of neutrality. This section will summarize the main current debates in the literature. The last section will provide an analytical summary of the last two sections, and provide recommendations for current humanitarian work in Lebanon.

A roundtable discussion was held around the topic of this case study both informing it and framing its limitations. some of the topics addressed in the roundtable varied from the difference between neutrality and impartiality in providing services for aid communities, the difference within international humanitarian organizations around ethics and principles of practice during war, as well as whether they are oriented by foreign state's agendas or not, experiences of communal engagements in aid and support during the 2006 war, the role of faith-based organizations, the inequalities of life care for and the different strategies one can take to provide a more community-based aid service during conflict and its aftermath.

\section{The Politics and relief during the July war: experiences of local-political forms of relief.}

Based on interviews conducted with several individuals who volunteered in the July War and were engaged in different forms of aid and relief initiatives, relief work organized by different local and political groups was considered to be first and foremost an act of engaged solidarity and popular mobilization against the war.2 In other words, "the work of relief in itself was the not the goal but the means employed to show solidarity and resistance to the war". $\underline{3}$ The relief and aid support initiatives that emerged as a reaction to the July war revealed that the act of providing aid was perceived as a political position against the Israeli war, in the sense that politics and aid were mutually constitutive of one another, where the work of relief produced a national and international solidarity campaign that in itself enriched the process of aid and made it efficient and productive. 4 While international humanitarian organizations imagined aid as separate from politics, local aid and politics during the July War formed and informed each other and were not necessarily in placed in a binary opposition an opposite binary form. 
Moreover, providing aid to war-affected communities during the conflict produced a process of political self-transformation for the individuals who volunteered and were part of volunteer-based initiatives. $\underline{5}$

This work of volunteering set the basis for a form of aid that can be described as locally committed and politically motivated. The form of local aid that emerged during the July War is quite different from the specific form of professionalization and standardization exerted by international humanitarian organizations on relief work. $\underline{6}$ It established a form of aid exchange between local actors and the affected community that transcended its monetary or material value and had a different affective and emotional influence on both the person receiving relief, and providing it. This form of aid also established a personal relationship between the affected communities and aid providers that affected the quality and depth of the needs expressed and satisfied during the war. Building engaged forms of solidarity with war-affected communities also had an effect on the type and complexity of the needs collected during war.

Moreover, many of the activists, experts and volunteers interviewed saw the politics of postwar reconstruction as a process that requires awareness, intervention and mobilization. 7 The influx of international humanitarian organizations, interventions, policies, funds by the end of the war and established a political economy of aid for reconstruction and rehabilitation that followed neutralized (i.e. professionalized, bureaucratized and standardized) channels, disengaging the aid from communities' needs and demands, rendering it a commodity. $\underline{8}$ Interviews have revealed that many volunteers and experts' aid reliefs clashed with global humanitarian policies that began to take shape after the war and some of whom tried to resist or work against, as is the case for trying to influence the reconstruction process in South Lebanon, $\underline{9}$ or trying to influence humanitarian psychological programs focusing on war trauma and PTSD.10 These new policies imposed a political economy of postwar reconstruction in terms of aid that materialized in funding, new concepts and notions that gained economic value, and an overall site for corruption and misuse of aid11. Thus political economy was literally translated into a 'market of aid', where NGO jargon, professionalization and expertise were seen as highly valued commodities on one hand, and as the way to produce rights, development and social change in Lebanon. This serves to show that neutral and standardized forms of humanitarian aid produce and enable and influence political economies of postwar aid.

On the other hand, humanitarian organizations sought to neutralize aid work and conform it under one process by making it a professionalized and unified work, thereby separating it from its emotional and subjective value, and rendering it into 'work' or a business. Politically engaged relief was perceived to be biased, not professional and overall an improper form of aid. Standardization of aid was seen as the most efficient way to neutralize it within the internal political tension.

\section{Critiques of the neutrality of humanitarian assistance from the literature}

The following section compiles and reviews academic and humanitarian literature on the principle of neutrality in humanitarian action. The latter has been a topic of debate between global humanitarian actors and critics, with Medecins Sans Frontieres (MSF) emerging out of the International Committee for the Red Cross (ICRC), holding the principle of "witnessing" as a replacement to ICRC's neutrality principle that was becoming more controversial.12 Another rupture within MSF created Medecins Du Monde with Bernard Kouchner as a founder, which adopted "the right to intervene" under any circumstances, including military intervention as a new and guiding principle of action. 13 These diverse 
humanitarian principles, ranging from neutrality to the humanitarian right to intervene beyond state sovereignty and approval, have challenged what was previously imagined to be a more unified set of ethical norms for humanitarian action, thereby raising critical debates on the politics of neutral humanitarian assistance, especially with the current confusion between military and humanitarian intervention.14 The critiques this section explores can be divided in the following three categories: 1) a critique of the new identity of humanitarianism rising after the fall of the Soviet Union; 2) a critique of the politics of life in humanitarian action; and 3) a critique of the political economy of psychological aid during war.

\section{The politics and ethics of the new humanitarianism}

One of the critiques of humanitarianism focuses on the recent development and changes it went through after the cold war that drastically shaped its identity and ethics.15 Contemporary debates on the purposes, principles and politics of humanitarianism attempt to recapture the unity and idealized purity of humanitarian identity, which is intrinsically tied to a presumed universality of action.16 While there have always been different "strands" or identities of humanitarianism, defined by different practices, organizations and principles, the International Committee for Red Cross (ICRC)'s definition17of humanitarian action, as neutral, independent and impartial relief action, was arguably the "industry standard" until the late 1980s.18 Humanitarian action in the post-cold war period however began to include development, gender equality, democracy promotion, human rights, and peace building activities that do not mesh well with principles of neutrality, impartiality and independence.19

The critique of the 'new' humanitarian identity therefore aims to raise questions and debates on the previously taken for granted - unity and purity in humanitarian identity, as well as its purported universality and neutrality. Humanitarianism ideally aspires at saving lives regardless of nationality, religion, culture or other identity markers. Its principles of impartiality, neutrality and humanity serve to establish it as a depoliticized and universal form of action. However, as more agencies became more closely linked to European/North American states and are committed to implementing Western ideologies, policies and values, humanitarianism's universality has been continuously critiqued as posing a moral threat to its very identity. $\underline{20}$

Another critique in the literature focuses on the reasons behind the increasing threat and targeting of humanitarian workers in conflict and post-conflict sites. Contrary to arguments that define these increasing threats and risks as an expression of a new world order that is becoming more violent and terrifying, Hammond argues that the difficulty in maintaining the humanitarian principles of neutrality and impartiality, and the adoption of European/North American values of democracy and human rights have made it hard for humanitarian workers to distinguish themselves from political parties and agents who are sometimes involved in conflicts. 21 It seems that both the humanitarian workers and the locals are confused as to who is whom since the boundaries of what constitutes humanitarian work is now blurred, especially that humanitarian intervention seem to arrive in parallel with political conflicts . Moreover, the militarization of humanitarian action has become a common feature of conflicts in many parts of the world.22 This has contributed to an inability to clearly distinguish between humanitarian workers as idealized aid-providers and as actors participating in and influencing the conflict itself. 


\section{The politics of life in humanitarian assistance}

This form of critique deals with the process through which humanitarianism as an institution of knowledge and intervention makes a decision on who deserves to be saved and who does not. 23 By relying on minutes of a meeting held by MSF during the Iraq war of 2003, Fassin shows how humanitarian workers engage in a dialectic discussion over the lives to be saved and the lives to be risked in order to decide who is worth risking a humanitarian worker's life for and who is not, which lives are worth saving and which lives worth risking. 24 Fassin argues that this dichotomy becomes conflated when a humanitarian intervention becomes also military, when military and humanitarian intervention become one. Even humanitarianism, an institution that believes in equal human rights and universal humanity, imprints specific values and meanings onto different lives and bodies.

By looking at the different forms of decisions taken by MSF in the 2003 Iraq war for example, the politics of life behind humanitarianism become clearer and more explicit. The humanitarian worker has the choice and freedom to sacrifice himself, while the Iraqi must be sacrificed.25 Both Fassin and Redfield argue that these two forms of life, the life to be saved and the life of the savior, are ontologically different and hierarchical. In that sense, humanitarian intervention therefore becomes an apparatus of regulation and classification through which lives are governed through the act of saving.

Another form of critique deals with the professionalization and commodification of suffering and conflicts. standardized and universal humanitarian interventions have managed to transfer, translate and mediate people's complex experiences of suffering into objective data that donor societies and agencies can read, where war becomes a technical problem that require a technical solution.26 Other critics have questioned, through case studies and programs from Northern Uganda, who has the right to be a "victim" within the humanitarian imaginary of suffering, where men for example are more difficult to be recognized by humanitarian indicators as an innocent and suffering refugees, like women and children. 27

\section{The political economy of trauma during war}

Another form of critique focuses mainly on the political economy of suffering as a consequence of war and humanitarian intervention and the adoption of global humanitarian "concepts" like trauma and PTSD. Erica Caple James is interested in the unintended consequences of humanitarian intervention in Haiti and what these interventions produced.28The state and non-state interventions intersected with the politics of local communities to contribute to the commodification of suffering, thus producing a political economy of trauma. 29

While these humanitarian interventions make suffering audible and visible, humanitarian psychology helps "authenticate categorize and legitimize" certain forms of suffering. 30 While these humanitarian interventions make suffering audible and visible, humanitarian psychology helps "authenticate categorize and legitimize" certain forms of suffering. 31 In some of her articles, James focuses on public testimony in Haiti, and the idea of "truth telling" in psychological rehabilitation and justice. 32 These public testimonies show the willingness of the state to acknowledge the "human rights culture", "democracy" and "human security": this is a marker for human rights performance, an outcome of humanitarian intervention that is constantly being demanded by funders. Through public testimonies in 
Haiti, narratives of suffering circulated and are performed and become commodified. 33 James's work generates questions concerning the efficacy of therapeutic initiatives aimed at "victims" and how emotional distress manifests in Haiti and is appropriated into a political economy market. These "trauma portfolios" represent a marker for humanitarian aid's success and for the authenticity and efficacy of humanitarian aid workers.34 This commodification of suffering contributes to an actual humanitarian market, where specific refugee experiences become valued, coveted and enacted in order to receive aid and legal status. James uses narrative to show the political economy of trauma, misery and truth and the channels through which people's embodied and narrated experiences of violence become commodified and a part of human rights performance.

\section{Recommendations for current humanitarian work}

Emergent local initiatives of aid and support during the July war posited a form of humanitarian work that was inseparable from a political engagement and solidarity with war-affected communities, thereby taking a stance against the war, and resisting it, through relief, aid and support. While international humanitarian organizations saw this form of aid to be non-neutral, and therefore non-professional or effective, they sought to standardize and unify humanitarian assistance in Lebanon, especially in the postwar period, enforcing policies, concepts of aid, programs, and relief procedures, reconstruction processes that were not in direct contact with the complex and local needs of the communities, who seem to lack any kind of participatory role in the reconstruction process.

However, the review of the critiques of the humanitarian principle of neutrality reveals that the apoliticalness of humanitarian assistance is in itself a political position that influences economies, decides who is worthy of being saved and assisted and who is not, and produces a specific politics of suffering from war. Moreover, the transformative history of humanitarianism from the principle of neutrality to the principle of witnessing and 'the right to intervene', have intersected with an increased incorporation of development, advocacy for human rights and gender equality, especially in post-conflict humanitarian programs. This has revealed the confused and paradoxical nature of humanitarianism as a neutral form of aid. $\underline{35}$

Moreover, international humanitarian organizations sought to neutralize aid in Lebanon by standardizing and professionalizing it. For them, the purpose of neutrality was to service individuals and communities regardless of religion, culture and gender. Neutrality serves to form a kind of humanitarian work that has to potential of being global and mobile across cultures and beliefs. However, global aid as imagined by humanitarian organizations, as mobile, accessible to all equally, became in reality bounded by donor state policies and European and North American values, concepts and assumptions; thus the imagined global and neutral interventions of humanitarian society became nonexistent.

Experts, academics and critics, along with local activists and aid workers, talk about a rupture in the principle of neutrality today, especially with the increase adoption of "humanitarian military interventions" and "just wars" by global powers. 36 Humanitarian internal debates around neutrality seem to focus on the intersection of neutrality in humanitarian assistance with faith-based international humanitarian organizations and the incorporation of religious spirituality in healing the suffering of war and disaster-affected communities, rather than clinical forms of interventions, seen as more neutral and standardized.37 Another notable debate is on the increasing role of the United Nations in managing 
and coordinating humanitarian interventions through the interagency guidelines, and how the politics of the UN intersect with humanitarian interventions. $\underline{38}$

Following these debates and the field experience and expertise from the July war, it is recommended that current humanitarian work and organizations in Lebanon should encourage and collaborate with politically engaged, committed and grassroots initiatives of aid and development. These initiatives and groups have the potential of building deep ties and relationships with the serviced communities, understand their needs and be creative in satisfying them outside of a bureaucratized and standardized procedure that might not always be compatible. Moreover, further professionalization and standardization of current humanitarian work have transformed it into a business-like act where the humanitarian worker has to detach herself emotionally and political from the crisis. It is recommended that a de-professionalization of aid and development work be established in order to ensure a more engaged and therefore more efficient support for the serviced communities.

\section{Conclusion}

The principle of humanitarian neutrality during war and conflict relied on a thick process of standardization, training and professionalization that turned aid, relief and support into a work of expertise provided by paid NGO workers. It turned relief into an aid market at the end of the July War, thereby de-politicizing the complex and structural needs of aid communities. In contrast, local volunteer activists and experts during the war saw relief as an inseparable mixture of politics and aid, which were mutually constitutive, predicating a somewhat national support for the war-affected communities. The debates and critiques of the neutrality argument in academic and humanitarian circles are also telling of the complex and paradoxical nature of humanitarianism today as it strives to remain apolitical in highly charged political contexts.

\section{Bibliography}

Miriam Ticktin, "When politics and ethics meet: the violence of humanitarianism in France", American Ethnologist, 33 (1), 2006, p. 33-49.

Craig Calhoun, "The idea of emergency: Humanitarian action and global (dis)order", Didier Fassin \& Mariella Pandolfi, Contemporary states of emergency, New York: Zone Books, 2010, p. 29-59.

Miriam Ticktin, "Casualties of Care: Immigration and the politics of humanitarianism in France", University of California Press (Eds). Didier Fassin \& Mariella Pandolfi. Contemporary states of emergency: the politics of military and humanitarian interventions, Zone Books, 2010 .

Didier Fassin Humanitarian Reason: A Moral History of the Present, University of California Press, 2011.

Peter Redfield. Life in crisis: the ethical journey of Doctors without borders. University of California Press, 2013.

Johanna Simeant, Interpreting the rise of international advocacy, Humanity: an international journal of 
human rights, humanitarianism and development, 5 (3), 2014.

Michael Barnett \& Thomas G. Weiss, Humanitarianism: a brief history of the present, in Barnett \& Weiss, Humanitarianism in Question: Politics, Power, Ethics (Eds), Cornell University Press, Ithaca: New York, 2008, p.1-48.

Laura Hammond, the power of holding humanitarianism hostage and the myth of the protective principles, In, Michael Barnett \& Thomas G. Weiss, Humanitarianism in Question: Politics, Power, Ethics (Eds), Cornell University Press, Ithaca: New York, 2008, p.172-196.

Didier Fassin, "Humanitarianism as a Politics of Life" Public Culture, Vol. 19 No. 3, 2007, pp 499-520. Peter Redfield, "Doctors, Borders and Life in Crisis", Cultural anthropology : journal of the Society for Cultural Anthropology, Vol. 20, No.3, 2005, pp.328-361.

Derek Summerfield, "A critique of seven assumptions behind psychological trauma programmes in waraffected areas", Social Science \& Medicine, Vol. 48 No. 10, 1999, p 1449-1462. Erica Caple James, "Ruptures, rights, and repair: The political economy of trauma in Haiti", Social Science \& Medicine, Vol 70, No.1, 2010. pp. 106-113.

Erica Caple James. "The political economy of 'trauma' in Haiti in the democratic era of insecurity", Culture, Medicine and Psychiatry, Vol.28, 2004, pp.127-249.

Schafer, Alison, "Spirituality and mental health in humanitarian contexts: An exploration based on World Vision Haiti earthquake response", Intervention: International Journal of Mental Health, Psychosocial Work \& Counselling in Areas of Armed Conflict, Vol 8, No.2, 2010. pp. 121-130.

Dakkak, Henia \& Izutu, Takashi, "Mental health and psychosocial support in UNFPA: Toward implementation of the IASC Guidelines on Mental Health and Psychosocial Support in Emergency Settings", Intervention: International Journal of Mental Health, Psychosocial Work \& Counselling in Areas of Armed Conflict, Vol 6, Issue 3 -4), 2008.

pp. 310-313. Lamia Moghnieh, Local forms of relief during the July War in 2006 and international humanitarian interventions: implications on community preparedness for war and conflict, Lebanon Support, 2015, https://civilsociety-centre.org/paper/local-forms-relief-during-july-war-2006-andinternational-humanitarian-interventions [ last accessed on July 4th 2015].

Miriam Ticktin, The Gendered Human of Humanitarianism: Medicalizing and politicizing Sexual Violence, Gender and History, 23 (2), 2011, p. 1468-0424.

Lamia Moghnieh, Local expertise and global packages of aid: the transformative role of volunteerism and locally engaged expertise of aid during the 2006 July War in Lebanon, Lebanon Support, 2015 https://civilsociety-centre.org/paper/local-expertise-and-global-packages-aid-transformative-rolevolunteerism-and-locally-engaged [Last accessed on August 11th, 2015].

-1. Lamia Moghnieh, Local forms of relief during the July War in 2006 and international 
humanitarian interventions: implications on community preparedness for war and conflict, Lebanon Support, 2015, https://civilsociety-centre.org/paper/local-forms-relief-during-julywar-2006-and-international-humanitarian-interventions [last accessed on July 4th 2015]. Lamia Moghnieh, Local expertise and global packages of aid: the transformative role of volunteerism and locally engaged expertise of aid during the 2006 July War in Lebanon, Lebanon Support, 2015

https://civilsociety-centre.org/paper/local-expertise-and-global-packages-aid-transformative-rolevolunteerism-and-locally-engaged [Last accessed on August 11th, 2015]

- 2. Interview with Bassem Chit, April 2013 ; Interview with Hiba Abbani, January 2015; Interview with Walid Abu Saifan, January 2015.

- $\underline{3}$. A conversation with Rabih Salah during the roundtable discussion of case study one, 23 April 2015.

- 4. Interview with Ghassan Makarem, February 2015: "The most important thing (about the relief provided) was the political form of mobilization mixed with a kind of a spontaneous expertise (that made people transfer the knowledge and skills they learned in their work to relief). There were a lot of experts interested in joining, like doctors and psychologists whom you never normally see in a political form of mobilization so I was happy to see them there. they created units [....]. In my opinion, The political mobilization or the political content of work was very important in samidoun because the country was divided then and some of the displaced communities were receiving aid in a non-dignified and respectful manner, no one reacted or responded to the needs of the war until 5 days after [...]. There was a direct response [from us]." Interview with Bernadette Daou, April 2013.

- 5. Lamia Moghnieh, Local expertise and global packages of aid: the transformative role of volunteerism and locally engaged expertise of aid during the 2006 July War in Lebanon, op.cit.

- 6. This was part of a discussion during the roundtable for case study two, 7 May 2015.

- 7. Interview with Abir Saksouk, April 2015; Interview with Ola Ataya, October 2014; Interview with Mohamad Ali Nayel, April 2013; Interview with Hiba Abbani, January 2015.

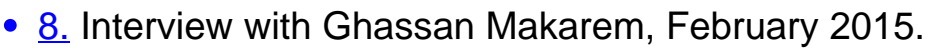

- 9. Lamia Moghnieh, Local expertise and global packages of aid: the transformative role of volunteerism and locally engaged expertise of aid during the 2006 July War in Lebanon, op. cit.

- 10. Lamia Moghnieh, Idem.

- 11. Interview with Mohamad Ali Nayel, April 2013: "I was managing of a (aid) basement in South Lebanon, local humanitarian organizations would come along with their foreign humanitarian colleagues who was supervising. they would ask me to show them the aid they distributed but they did not give us anything. At the end the local humanitarian woman told me in Arabic to just say that I received aid from that international NGO. I was shocked." (translated edited quote)...

- 12. Didier Fassin, Humanitarian Reason: A Moral History of the Present, University of California Press, 2011; Peter Redfield, Life in crisis: the ethical journey of Doctors without borders. University of California Press, 2013.

- 13. Didier Fassin \& Mariella Pandolfi, Contemporary states of emergency: the politics of military and humanitarian interventions, Zone Books, 2010.

- 14. Didier Fassin \& Mariella Pandolfi, op.cit.

- 15. Michael Barnett \& Thomas G. Weiss, Humanitarianism in Question: Politics, Power, Ethics (Eds), Cornell University Press, Ithaca: New York, 2008. 
- 16. Michael Barnett \& Thomas G. Weiss, op.cit, p.1-48.

- 17. The seven principles of humanitarian action according to the International Committee of Red Cross (ICRC) are: Humanity, Impartiality, Neutrality, Independence, Voluntary Service, Unity and Universality (https://www.icrc.org/eng/resources/documents/misc/fundamental-principles... [ last accessed August 11th, 2015]

- 18. Michael Barnett \& Thomas G. Weiss, op.cit, p.1-48

- 19. Michael Barnett \& Thomas G. Weiss, Idem.

- 20. Michael Barnett \& Thomas G. Weiss, Idem.

- 21. Laura Hammond, The power of holding humanitarianism hostage and the myth of the protective principles, In, Michael Barnett \& Thomas G. Weiss, Humanitarianism in Question: Politics, Power, Ethics (Eds), Cornell University Press, Ithaca: New York, 2008, p.172-196.

- 22. Laura Hammond, op.cit.

- 23. Didier Fassin, "Humanitarianism as a Politics of Life" Public Culture, Vol. 19 No. 3, 2007, pp 499-520; Peter Redfield, "Doctors, Borders and Life in Crisis", Cultural anthropology : journal of the Society for Cultural Anthropology, Vol. 20, No.3, 2005, pp.328-361.

- 24. Didier Fassin, op.cit, pp 499-520.

- 25. Didier Fassin, op.cit, pp 499-520; Peter Redfield, "Doctors, Borders and Life in Crisis", Cultural anthropology : journal of the Society for Cultural Anthropology, Vol. 20, No.3, 2005, pp.328-361.

- 26. [Derek Summerfield, "A critique of seven assumptions behind psychological trauma programmes in war-affected areas", Social Science \& Medicine, Vol. 48 No. 10, 1999, p 1449-1462; Craig Calhoun, "The idea of emergency: Humanitarian action and global (dis)order", Didier Fassin \& Mariella Pandolfi, Contemporary states of emergency, New York, Zone Books, 2010, p. 29-59.

- 27. Miriam Ticktin, "When politics and ethics meet: the violence of humanitarianism in France", American Ethnologist, 33 (1), 2006, p. 33-49; and Miriam Ticktin, The Gendered Human of Humanitarianism: Medicalizing and politicizing Sexual Violence, Gender and History, 23 (2), 2011, p. 1468-0424.

- 28. Erica Caple James, "Ruptures, rights, and repair: The political economy of trauma in Haiti", Social Science \& Medicine, Vol 70, No.1, 2010. pp. 106-113; Erica Caple James. "The political economy of 'trauma' in Haiti in the democratic era of insecurity", Culture, Medicine and Psychiatry, Vol.28, 2004, pp.127-249.

- 29. Erica Caple James, "Ruptures, rights, and repair: The political economy of trauma in Haiti", op.cit, pp. 106-113; Erica Caple James, "The political economy of 'trauma' in Haiti in the democratic era of insecurity", op.cit, pp.127-249.

- 30. Erica Caple James, "Ruptures, rights, and repair: The political economy of trauma in Haiti", op.cit, pp. 106-113; Erica Caple James, "The political economy of 'trauma' in Haiti in the democratic era of insecurity", op.cit, pp.127-249.

- 31. Erica Caple James, "The political economy of 'trauma' in Haiti in the democratic era of insecurity", op.cit, pp.127-249.

- 32. Erica Caple James, Idem.

- 33. Idem.

- 34. Erica Caple James, "Ruptures, rights, and repair: The political economy of trauma in Haiti", Social Science \& Medicine, op.cit, pp. 106-113.

- 35. Johanna Simeant, Interpreting the rise of international advocacy, Humanity: an international 
journal of human rights, humanitarianism and development, 5 (3), 2014.

- 36. Didier Fassin \& Mariella Pandolfi, op.cit, 2010.

- 37. Schafer, Alison, "Spirituality and mental health in humanitarian contexts: An exploration based on World Vision Haiti earthquake response", Intervention: International Journal of Mental Health, Psychosocial Work \& Counselling in Areas of Armed Conflict, Vol 8, No.2, 2010. pp. 121-130.

- 38. Dakkak, Henia \& Izutu, Takashi, "Mental health and psychosocial support in UNFPA: Toward implementation of the IASC Guidelines on Mental Health and Psychosocial Support in Emergency Settings", Intervention: International Journal of Mental Health, Psychosocial Work \& Counselling in Areas of Armed Conflict, Vol 6, Issue 3 -4), 2008. pp. 310-313. 